\title{
Limu Granitic magma evolution and formation of W-Sn and Ta-Nb-Sn-W deposits, Guangxi, China
}

\author{
HUAYING LIANG ${ }^{1}$, WENTIAN HUANG ${ }^{2}$, JiNG WU ${ }^{3}$ \\ ${ }^{1}$ CAS Key Lab of Mineralogy and Metallogeny, \\ lianghy@gig.ac.cn \\ ${ }^{2}$ CAS Key Lab of Mineralogy and Metallogeny, \\ ita19@163.com \\ ${ }^{3}$ College of Rresource and Metallurgy, Guangxi University, \\ Nanning, China, 41734291@qq.com
}

A Ggranite complex associated both with W-Sn and Ta$\mathrm{Nb}$ deposits are rare found in south China although W-Sn and $\mathrm{Ta}-\mathrm{Nb}$ deposits are related to highly fractionated granite. The Limu granite complex in Guangxi, south China hosts W-Sn quartz vein deposit in second stage lepidolite granite and disseminated Ta-Nb-Sn-W deposits in third stage topazlepidolite granite. This work reported muscovite ${ }^{40} \mathrm{Ar} /{ }^{39} \mathrm{Ar}$ and zircon $\mathrm{U}-\mathrm{Pb}$ ages, geochemical and $\mathrm{Nd}$ isotopic compositions of the granite complex to shed light on magmatic evolution and genesis of different type mineralizaton. Muscovite from W-Sn quartz vein has ${ }^{40} \mathrm{Ar} /{ }^{39} \mathrm{Ar}$ plateau age of $213.7 \pm 1.1 \mathrm{Ma}$. Two hydorthermal zricons and two muscovite sampels from third stage granite assoiated with disseminated $\mathrm{Ta}-\mathrm{Nb}-\mathrm{Sn}-\mathrm{W}$ mineralization yielded similar U-Pb ages of ca 203 and 208Ma, respectively. The Limu granite complex is peraluminous $(\mathrm{A} / \mathrm{CNK}>1.1)$ with negative $\varepsilon \mathrm{Nd}(\mathrm{t})$ values $(-8.5$ to -9.7$)$ and $\mathrm{T}_{\mathrm{DM} 2}$ ages of 1780-1685 Ma, indicating they were derived from partial melting of Paleoproterozoic basement. Low $\mathrm{Zr} / \mathrm{Hf}(<13)$ and $\mathrm{Nb} / \mathrm{Ta}(<5)$ ratios and the tetrad effect in rare-earth-element patterns of the second- and third-stage granites indicate that the magmas were highly evolved and underwent late-stage exsolution of fluids. Disseminated columbite, tantalite and cassiterite are semi-enclosed by quartz or occurr in the gaps between magmatic K-feldspar and albite without either alteration or reaction rims, suggesing they are crystallized contemporaneously. These features indicate that quartz vein mineralization was formed at ca. $214 \mathrm{Ma}$ and was hydrothermal in origin, whereas $\mathrm{Ta}-\mathrm{Nb}-\mathrm{Sn}-\mathrm{W}$ mineralization was formed at ca. 208-203 Ma and was of magmatichydrothermal origin. South China underwent not only the Yuanshan largescale- but also Indosinian strong- critical metal mineralization. Mantle-derived heat from a long-lived magma chamber was suggested for the high-temperature anatexis that formed the Limu Ta-Nb-Sn-W-rich melts during the Indosinian Orogeny.

This work was supported by the Chinese NSF (41772065). 